\title{
Nutrition Knowledge and Healthy Food Choices After Participating in Online Nutrition Education in Overweight Adolescents
}

\author{
* $1^{\text {st }}$ Khairunnisa Nadya Risti \\ Nutrition Science Study Program \\ Postgraduate \\ Universitas Sebelas Maret \\ Surakarta, Indonesia \\ dheanadya97@gmail.com
}

\author{
$2^{\text {nd }}$ Eti Poncorini Pamungkasari \\ Medical Study Program \\ Universitas Sebelas Maret \\ Surakarta, Indonesia \\ etiponco@staff.uns.ac.id
}

\author{
$3^{\text {rd }}$ Suminah \\ Agricultural Extension and \\ Communication Study Program \\ Universitas Sebelas Maret \\ Surakarta, Indonesia \\ suminah@staff.uns.ac.id
}

\begin{abstract}
The prevalence of overweight in adolescents can occur due to unhealthy food choice behavior. Nutrition knowledge in adolescents is an important factor for shaping behavior in healthy food choices. Increased nutrition knowledge can be achieved by conducting nutrition education. This study aimed to analyze the effectiveness of nutrition education through whatsapp, lecture and online game on nutritional knowledge, healthy food choices before and after treatment. This study was a quasy experiment research with two group pretest-posttest design. Sampling in the study used purposive sampling technique and obtained 32 subjects in each treatment, so that the total subject was 64 students aged 15-17 yearsold. Nutrition knowledge and healthy food choice data were obtained from structured questionnaires that had been tested for validity and reliability. T test used in this study was the Mann Whitney $U$ test. The results indicated that the number of adolescents with good knowledge after participating in nutrition education increased to $56.3 \%$ (whatsapp group) and $65.6 \%$ (lecture and online game group). While the number of adolescents with healthy food choice also increased to $62.5 \%$ (whatsapp group) and $\mathbf{6 5 . 6 \%}$ (lecture and online game group) after participating in nutrition education. The results of Mann Whitney $U$ test on knowledge indicated $p$-value $=0.015$ and healthy food choice obtained $p$-value $=0.003$. There was a difference between nutrition knowledge and healthy food choice among overweight adolescents participating in nutrition education through WhatsApp and lecture and online game.
\end{abstract}

Keywords - online nutrition education, nutrition knowledge, healthy food choice, overweight adolescents

\section{INTRODUCTION}

Indonesia is a developing country with a sizeable population. A large number of adolescents will be prone to degenerative diseases when they reach adulthood and old age if they do not apply healthy lifestyles properly. Transitional period in adolescence is often a factor that causes health problems, especially nutrition problems in adolescents. The transitional period from childhood to adolescence indirectly requires adolescents to regulate their eating habits and diet, the importance of adopting healthy eating habits during this period can be a key in preventing nutritional problems such as overweight and obesity[1].
The problem of overweight and obesity in adolescents is closely related to poor eating habits. Based on health research conducted by the Indonesian Ministry of Health (2018) [2], Indonesian adolescents aged 15-19 years old commonly consume sweet foods $(41.0 \%)$, sweet drinks $(56$, $43 \%)$, salty foods $(30.5 \%)$, and fatty foods $(43.8 \%)$ more than once a day which is a predictor of overweight in adolescents. In Indonesia, the prevalence of overweight in adolescents aged 15-19 years old in 2018 was 9.5\%, while that in Central Java was $7.9 \%$.

Prevalence of overweight and level of consumption of sugar, salt and fat are high among adolescents, indicating that there is a lack of knowledge about healthy eating patterns so that provision of nutrition education is important to improve knowledge about nutrition, improve diet and choose healthier foods [1,3]. Nutrition education is effective if it is carried out using appropriate media and methods to facilitate the delivery and understanding of materials presented [4].

Research by Pakhiretal, stated that the delivery of nutrition education materials by lecture method and flipchart media has been effective in increasing nutrition knowledge [5]. Similar study using smart ball game and socialization methods indicated significant differences in nutrition knowledge, but the nutrition knowledge value after participating in nutrition education is higher in adolescents participating in nutrition education through games than through socialization [6]. At present, most nutrition education are delivered conventionally and only a few people use online media as a means of delivering educational material.

Adolescents are in a transitional period from childhood to adulthood. Delivery of education through games will be learned more effectively by them, but in the current globalization era, adolescents are more likely to use mobile phones as a device for playing games, chatting, using social media and searching for information [7]. Thus, in this study, the researcher was interested to examine the effectiveness of nutrition education using online media (whatsapp and lecture followed by online game) that can be accessed through mobile phones for overweight adolescents. 


\section{MATERIAL AND METHOD}

The research design use dwasquasy experiment with two group pretest-posttest design. Sampling in this study used purposive sampling technique with the following criteria: adolescents aged 15-17 years old and attending school in Surakarta, have overweight nutritional status $(>1$ SD to 2 SD), can use and have an android phone, and have not been ill in the last three months. Based on these criteria, 32 subjects were obtained in each treatment, so that the total subjects was 64 students aged 15-17 years old.

This study was conducted at SMAN 05 and SMAS Batik 1 Surakarta. Research locations were selected based on the highest prevalence of overweight adolescents in Surakarta, namely Jebres and Banjarsari Sub-districts, and the schools represented public and private schools. Before conducting the study, a screening process was conducted (measurement of body weight and height) to obtain subjects with overweight nutritional status and assess their nutritional status using the WHO AnthroPlus software (Z-Score, $\mathrm{BMI} / \mathrm{U})$. Z-Score values obtained were categorized based on growth categories from the World Health Organization (2007), consisting of normal (-2 SD to 1 SD), overweight (>1 $\mathrm{SD}$ to $2 \mathrm{SD}$ ), obesity (>2 SD). The distribution of treatment groups was carried out randomly [8]. A total of 32 subjects were grouped for nutrition education through whatsapp treatment by providing materials in the form of an explanation of balanced nutrition in adolescents through whatsapp group and 32 respondents were grouped for nutrition education through lecture and online game treatment once. The online game used in this study was an online time-based interactive quiz game available on google page called Quizziz. Quizziz link can be accessed and developed according to quiz questions that have been created on the internet. The technical implementation of online game starts from making questions adjusted to the material presented. Furthermore, the researcher created a quizziz account to host the quizzes, so that when the link was shared to research subjects, the researcher can get immediate feedback on getting the subjects' answers correct or incorrect. The total correct answers were ranked and the winner was selected from the game and given a reward at the end of the game.

Nutrition knowledge and healthy food choice data were obtained from structured questionnaires that had been tested for validity and reliability. Data analysis was performed using the Mann Whitney $U$ test because the data are not normally distributed. This study has obtained ethical approval from Health Research Ethics Commission (KEPK) of Universitas Sebelas Maret No.035/UN27.06. 6.1/KEPK/EC/2020.

\section{RESULT AND DISCUSSION}

TABLE I. DISTRIBUTION OF CHARACTERISTICS OF RESPONDENTS BY TREATMENT GROUP

\begin{tabular}{ccc}
\hline Variable & $\begin{array}{c}\text { Group } \\
\text { Nutrition Education } \\
\text { through Whatsapp }\end{array}$ & $\begin{array}{c}\text { Nutrition Education through } \\
\text { Lecture and Online Game }\end{array}$ \\
\hline Age & $9(28.1 \%)$ & $0(0 \%)$ \\
15 & $22(68.8 \%)$ & $13(40.6 \%)$ \\
16 &
\end{tabular}

\begin{tabular}{ccc}
17 & $1(3.1 \%)$ & $19(59.4 \%)$ \\
Total & $32(100 \%)$ & $32(100 \%)$ \\
Gender & & \\
Male & $17(53.1 \%)$ & $8(25 \%)$ \\
Female & $15(46.9 \%)$ & $24(75 \%)$ \\
Total & $32(100 \%)$ & $32(100 \%)$ \\
Allowance & & \\
$<$ Rp 10.000 & $2(6.3 \%)$ & $2(6.3 \%)$ \\
Rp 10.000- & $20(62.5 \%)$ & $5(78.1 \%)$ \\
20.000 & & $32(15.6 \%)$ \\
$>$ Rp 20.000 & $10(31.5 \%)$ & \\
Total & $32(100 \%)$ & \\
\hline
\end{tabular}

\begin{tabular}{|c|c|c|}
\hline \multicolumn{3}{|c|}{ Peer influence } \\
\hline Positive & $11(34.4 \%)$ & $16(50 \%)$ \\
\hline Negative & $21(65.6 \%)$ & $16(50 \%)$ \\
\hline Total & $32(100 \%)$ & $32(100 \%)$ \\
\hline
\end{tabular}

The subjects in this study were over weigh thigh school adolescents ranging in age between 15-17 years old. A total of 64 respondents were selected and divided into two treatment groups namely nutrition education through whatsapp and through lecture followed by online game on mobile phones. Table 1 shows the distribution of respondents' characteristics by gender. The number of female students is higher than male students. This is because female sex hormones influence body weight. Based on the distribution of allowance, the average allowance of 64 subjects ranges from Rp10,000 - Rp20,000 a day. This can affect amount and types of food consumed. Based on Arisdanni \& Buanasita's study, the amount of allowance can be a factor in the prevalence of overweight and obesity [9].

High school adolescents commonly show unstable trait and are easy to be influenced by the environment. If adolescents are not provided with proper understanding, it can lead to errors in various ways, including in the healthy food choices. Based on table1,it can be seen that negative peer influence is higher than positive peer influence. Some studies stated that higher negative peer influence will affect the habits in choosing unhealthy snacks and daily foods [9][10] AND HEALTHY FOOD CHOICES BEFORE AND AFTER PARTICIPATING IN NUTRITION EDUCATION

\begin{tabular}{|c|c|c|c|c|c|}
\hline \multirow{2}{*}{\multicolumn{2}{|c|}{ Variable }} & \multicolumn{2}{|c|}{$\begin{array}{l}\text { Nutrition Education } \\
\text { through Whatsapp }\end{array}$} & \multicolumn{2}{|c|}{$\begin{array}{c}\text { Nutrition Education } \\
\text { through Lecture and } \\
\text { Online Game }\end{array}$} \\
\hline & & $\mathbf{n}$ & $\%$ & $\mathbf{N}$ & $\%$ \\
\hline \multicolumn{6}{|c|}{ Nutrition knowledge } \\
\hline \multirow[t]{2}{*}{ Before } & Good & 4 & 12.5 & 4 & 12.5 \\
\hline & Poor & 28 & 87.5 & 28 & 87.5 \\
\hline \multirow[t]{2}{*}{ After } & Good & 18 & 56.3 & 21 & 65.6 \\
\hline & Poor & 14 & 43.8 & 11 & 34.4 \\
\hline \multicolumn{6}{|c|}{ Healthy Food Choices } \\
\hline \multirow[t]{2}{*}{ Before } & Good & 20 & 62.5 & 16 & 50.0 \\
\hline & Poor & 12 & 37.5 & 16 & 50.0 \\
\hline \multirow[t]{2}{*}{ After } & Good & 20 & 62.5 & 21 & 65.6 \\
\hline & Poor & 12 & 37.5 & 11 & 34.4 \\
\hline
\end{tabular}

Table 2 shows an increasing number of adolescents in nutrition knowledge and healthy food choices before and after participating in nutrition education. The results indicate that the number of respondents with good nutrition 
knowledge in nutrition education through WhatsApp treatment increases to $18(56.3 \%)$ and the number of respondents with good nutrition knowledge in nutrition education through lecture and online game treatment increases from $4(12.5 \%)$ to $21(65.6 \%)$. Healthy food choices variable after treatment also increases towards better food choices, the number of respondents with good food choices in nutrition education through lecture and online game increases from16 $(50 \%)$ to $21(65.6 \%)$ respondents. However, there is no change in healthy food choices when seeing from the number of respondents in nutrition education through WhatsApp treatment even though the number of adolescents with good food choices is higher.

Based on table 2, it can be seen that social media is an attractive media in intervening adolescents so as to increase nutrition knowledge and provide positive results in every treatment [11]. However, intervention conducted through social media such as WhatsApp cannot ensure that all participants read and understand the material provided [12] so that the behavior is formed according to the individual needs. If they need to obtain information, then they will pay attention and provide good feedback and vice versa. Because adolescence is a transitional period, a game can be the fastest means to absorb information and can change behavior for the better. Gambir \& Nopriantini's study, stated that increased knowledge is proven to be higher in nutrition education intervention using lecture and game compared to intervention using socialization [6].

TABLE III. DIFFERENCE IN NUTRITION KNOWLEDGE VALUES, HEALTHY FOOD CHOICES BETWEEN WHATSAPP GROUP AND LECTURE WITH ONLINE GAME GROUP

\begin{tabular}{|c|c|c|c|c|c|c|}
\hline \multirow[b]{2}{*}{ Variable } & \multicolumn{2}{|c|}{ Pre-NutritionEducation } & \multirow[b]{2}{*}{ p-value } & \multicolumn{2}{|c|}{ Post-NutritionEducation } & \multirow[b]{2}{*}{ p-value } \\
\hline & $\begin{array}{c}\text { Nutrition } \\
\text { Education through } \\
\text { Whatsapp }\end{array}$ & $\begin{array}{c}\text { Nutrition } \\
\text { Education } \\
\text { through Lecture } \\
\text { and Online Game }\end{array}$ & & $\begin{array}{l}\text { Nutrition } \\
\text { Education through } \\
\text { Whatsapp }\end{array}$ & $\begin{array}{c}\text { Nutrition } \\
\text { Education } \\
\text { through Lecture } \\
\text { and Online Game }\end{array}$ & \\
\hline Nutrition Knowledge & & & & & & \\
\hline $\begin{array}{l}\text { Minimum } \\
\text { Maximum } \\
\text { Mean } \pm \text { SD }\end{array}$ & $\begin{array}{c}35.00 \\
65.50 \\
52.50 \pm 8.91\end{array}$ & $\begin{array}{c}27.50 \\
70.00 \\
52.89 \pm 10.51\end{array}$ & 0.736 & $\begin{array}{c}\begin{array}{c}42.50 \\
7.50 \\
62.03 \pm 6.67\end{array} \\
6\end{array}$ & $\begin{array}{c}25.00 \\
87.00 \\
69.80 \pm 16.66\end{array}$ & 0.015 \\
\hline Healthy Food Choice & & & & & & \\
\hline $\begin{array}{l}\text { Minimum } \\
\text { Maximum } \\
\text { Mean+SD } \\
\end{array}$ & $\begin{array}{c}46.00 \\
1100.00 \\
119.37 \pm 26.58 \\
\end{array}$ & $\begin{array}{c}89.00 \\
126.00 \\
104.658 .28\end{array}$ & 0.001 & $\begin{array}{c}50.00 \\
162.00 \\
122.78 \pm 25.99\end{array}$ & $\begin{array}{c}94.00 \\
129.00 \\
111.71 \pm 7.38\end{array}$ & 0.003 \\
\hline
\end{tabular}

Basedontable3,theresultsshowthatthemean of nutrition knowledge in pre-nutrition education through WhatsApp is 52.50 with the maximum value of 65.00 and the mean of nutrition knowledge in pre-nutrition education through lecture and online game is 52.89 with the maximum value of 70.00. In post-nutrition education through WhatsApp, the meanofnutritionknowledgeincreasesto62.03with the maximum value of 72.50 . Whereas the mean of nutrition knowledge in post-nutrition education through lecture and online game increases to 69.80 with the maximum value of 87.50. T-test results in post-nutrition education using the Mann Whitney $U$ test obtain $p$-value $=0.015(<0.005)$, meaning that $\mathrm{HO}$ is rejected or there is a difference in nutrition knowledge between nutrition education through WhatsApp and nutrition education through lecture and online game.

Based on table 3, the results show that nutrition education through WhatsApp and lecture with online game have been effective in increasing nutrition knowledge in high school adolescents. This is because in the current globalization era, high school students frequently access social media and internet, both as a means of communication, searching for information or playing online games at home or in public places [13]. High school students are in transitional period from childhood to adulthood and spend a lot of time playing video games, causing an increase in knowledge in lecture and online game treatment group which is consistent with the development of the millenial adolescents today. Holzmann et al study, stated that if adolescents play nutritional education digital game, their interest in nutritional information will increase which can be seen from their enthusiasm while playing the educational games provided [14]. The same finding can be seen in the results of this study. When adolescents participated innutrition education through lecture and quizziz online game, they were enthusiastic and enjoyed the course of nutrition education. Thus, they can easily answer the nutrition knowledge questions provided.

Healthy food choice variable also shows a difference in the mean score. In table 3, it can be seen that nutrition education before intervention through WhatsApp had a higher mean score (119.37) compared to nutrition education through lecture and online game (104.65). Similar results were found in both treatments after nutrition intervention, nutrition education through WhatsApp had a higher mean score compared to nutrition education through lecture and online game treatment. P-value obtained after participating in nutrition education is $\mathrm{p}=0.003(<0.005)$, meaning that $\mathrm{HO}$ is rejected or there is a difference in the mean score of healthy food choices between nutrition education through WhatsApp and nutrition education through lecture and quizziz online game.

Diferen case with nutrition knowledge variable, nutrition education through WhatsApp has greater effect on healthy food choices in overweight adolescents. Zaki \& Sari's study (2019) stated that an increase in the response of knowledge in this case such as healthier food choices can occur when receiving information through infographics sent via WhatsApp during education. Brain is able to quickly process information conveyed visually so that information can be received more quickly compared to the delivery of information manually as in the delivery of nutrition education through lecture and online game [15]. Ahmad et al study (2018) also stated that the provision of intervention using WhatsApp can affect eating behavior to be better, so as to reduce the prevalence of overweight and obesity in adolescents [16].

Nutrition education through WhatsApp has better effectiveness in changing behavior because the control of receiving information delivered via WhatsApp depends on each individual. If there is a need to find out information about nutrition, then one will pay close attention to the material provided, as in this study, nutrition education through WhatsApp get feedback in the form of questions about nutrition and ways to reduce and prevent over weight from some research subjects that need to obtain nutritional information, while some other research subjects receive messages on WhatsApp without reading the material provided [12]

This study found that nutrition education through lecture and quizziz online game had no significant effect on healthy food choices compared to nutrition education through WhatsApp. This finding is consistent with Sen et al study, that there is no significant effect between nutrition education through game and behavior change [17].Their study stated 
that behavior can be formed properly if they participate in nutrition education through game and there is family support, so that knowledge gained through game can be applied in choosing healthy foods at home through the support of family members. The limitation of this study is that the researcher did not conduct intervention in nutrition education that included families in its implementation, so that the results of nutrition education could not represent success in choosing healthy foods in daily life, but had significant results in increasing nutritional knowledge in overweight adolescents.

\section{CONCLUSION}

In this study, there was a difference in nutrition knowledge and healthy food choices between WhatsApp treatment and lecture and online game treatment before and after participating in nutrition education for over-weight adolescents. Asseeninthe results of this study, nutrition education through WhatsApp and through lecture and online game can improve nutrition knowledge and healthy food choices in over weight adolescents.

\section{ACKNOWLEDGMENT}

I would like to thank Mr. Ambang at SMA Batik 1 Surakarta and Mrs. Lestari at SMAN 05 Surakarta for their contribution to the completion of this study.

\section{REFERENCES}

[1] D. Milosavljevic, M. L. Mandic, and I. Banjari, "Nutritiona knowledge and dietary habits survey in high school population," Coll Antropol, vol. 39, no. 1, pp. 101-107, 2015.

[2] Kemenkes RI, "Laporan Nasional Hasil Riset Kesehatan Dasar (Riskesdas) Indonesia tahun 2018," Riset Kesehatan Dasar 2018. pp. 68-72, 2019.

[3] J. Hamulka, L. Wadolowska, M. Hoffmann, J. Kowalkowska, and K. Gutkowska, "Effect of an education program on nutrition knowledge, attitudes toward nutrition, diet quality, lifestyle, and body composition in polish teenagers. The $\mathrm{ABC}$ of healthy eating project: Design, protocol, and methodology," Nutrients, vol. 10, no. 10, 2018, doi: 10.3390/nu10101439.

[4] N. R. D. Safitri, "Pengaruh Edukasi Gizi dengan Ceramah dan Booklet Terhadap Peningkatan Pengetahuan," Skripsi Undip, vol. 5 , no. 4, pp. 374-380, 2016

[5] A. Pakhri, C. Chaerunnimah, and R. R, "Edukasi Gizi terhadap Pengetahuan dan Kebiasaan Jajan pada Siswa SMP Negeri 35
Makassar," Media Gizi Pangan, vol. 25, no. 1, p. 77, 2018, doi: 10.32382/mgp.v25i1.65.

[6] J. Gambir and N. Nopriantini, "Penerapan Model Edukasi Gizi terhadap Perilaku Sarapan pada Anak Sekolah Dasar," J. Vokasi Kesehat., vol. 4, no. 2, p. 85, 2018, doi: 10.30602/jvk.v4i2.133.

[7] S. Gifary and I. Kurnia N, "INTENSITAS PENGGUNAAN SMARTPHONE DAN PERILAKU KOMUNIKASI (Studi Pada Pengguna Smartphone di Kalangan Mahasiswa Program Studi Ilmu Komunikasi Universitas Telkom)," J. Sosioteknologi, vol. 14, no. 2, pp. 170-178, 2015, doi: 10.5614/sostek.itbj.2015.14.2.7.

[8] W. H. Organization, "Growth reference 5 -19 years." 2007, [Online].Available: https://www.who.int/growthref/who2007_bmi_for_age/en/.

[9] Arisdanni and A. N. Buanasita, "Hubungan Peran Teman , Peran Orang Tua , Besaran Uang Saku dan Persepsi Terhadap Jajanan Dengan Kejadian Gizi Lebih Pada Anak Sekolah," Amerta Nutr., pp. 189-196, 2018, doi: 10.20473/amnt.v2.i2.2018.189-196.

[10] D. Thiruselvakumar, K. Sinuvasan, S. C. R, and E. Venkatesh, "Factors affecting food choice and attitude of choosing food items among adolescents in South India," Int. J. Sci. Res. Publ., vol. 4, no. 4, pp. 1-3, 2014.

[11] M. M. Chau, M. Burgermaster, and L. Mamykina, "The use of social media in nutrition interventions for adolescents and young adults- $\mathrm{A}$ systematic review," Int. J. Med. Inform., vol. 120, pp. 77-91, 2018, doi: 10.1016/j.ijmedinf.2018.10.001.

[12] L. Fernandez-Luque et al., "Implementing $360^{\circ}$ Quantified Self for childhood obesity: Feasibility study and experiences from a weight loss camp in Qatar," BMC Med. Inform. Decis. Mak., vol. 17, no. 1, pp. 1-13, 2017, doi: 10.1186/s12911-017-0432-6.

[13] E. P. Juwita, D. Budimansyah, and S. Nurbayani, "Peran Media Sosial Terhadap Gaya Hidup Siswa," Sosietas, vol. 5, no. 1, 2015, doi: 10.17509/sosietas.v5i1.1513.

[14] S. L. Holzmann, F. Dischl, H. Schäfer, G. Groh, H. Hauner, and C. Holzapfel, "Digital Gaming for Nutritional Education: A survey on preferences, motives, and needs of children and adolescents," J. Med. Internet Res., vol. 21, no. 2, pp. 1-10, 2019.

[15] I. Zaki and H. P. Sari, "Edukasi Gizi Berbasis Media Sosial Meningkatkan Pengetahuan Dan Asupan Energi- Protein Remaja Putri Dengan Kurang Energi Kronik (Kek)," Gizi Indones., vol. 42, no. 2, p. 111, 2019, doi: 10.36457/gizindo.v42i2.469.

[16] N. Ahmad, Z. M. Shariff, F. Mukhtar, and M.-S. Lye, "Family-based intervention using face-to-face sessions and social media to improve Malay primary school children's adiposity: a randomized controlled field trial of the Malaysian REDUCE programme," Nutr. J., vol. 17, p. 74,2018

[17] M. Sen, A. Uzuner, M. Akman, A. T. Bahadir, N. O. Borekci, and E. Viggiano, "Examination of a board game approach to children's involvement in family-based weight management vs. traditional family-based behavioral counseling in primary care," Eur. J. Pediatr., vol. 177, no. 8, pp. 1231-1238, Aug. 2018, doi: 10.1007/s00431-0183177-z. 